\title{
Lateral Placentation by Ultrasonography: A Simple Predictor of Preeclampsia
}

\author{
Anuja V Bhalerao, Sayali Kulkarni, Savita Somalwar
}

\begin{abstract}
Introduction: P reeclampsia is a disease of trophoblastic tissue. it is a complex clinical syndrome involving multiple organ systems and still remains the principle cause of maternal and perinatal morbidity and mortality. The search for an ideal predictive test is still on, and preventive measures for preeclampsia remain a challenging entity.
\end{abstract}

\section{Aims and objectives:}

1. To examine the relation between placental location and development of preeclampsia.

2. To study the pregnancy outcome in terms of mode of delivery and birth weight of all babies.

Research question: Does lateral placentation on ultrasonography at 20 to 24 weeks of gestation predict development of preeclampsia?

A detailed demographic history, gravidity, parity, history of abruption placenta, hypertension, preeclampsia, IUD, gestational diabetes were taken. General examination, including weight, blood pressure, vital signs was done. Detailed obstetric examination was done.

Ultrasonography was done for all women between 20 and 24 weeks of gestation, and placenta was classified as central when it was between the RT and LT side of uterus irrespective of being anterior, posterior or fundal. When $75 \%$ or more of placenta was on one side of midline, it was classified as lateral.

All women with central and lateral placenta were followed up till development of preeclampsia as per ACOG guidelines and later till delivery to see the outcome of pregnancy.

Observations: While recruiting, there was no bias on low-risk and high-risk groups but, at the end of the study, we found 182 women with high-risk factors and 281 women with low-risk factors.

A total of 71 pregnant women developed preeclampsia, of whom 52/71 (73.23\%) had laterally situated placenta. This relationship seems to be significant. There was no relation of placental position and mode of delivary. The cesarean rate was $26.78 \%$ and normal delivaries being $73.21 \%$. Of the cesareans, $76(16.41 \%)$ were having centrally located placenta and 48 $(10.36 \%)$ had laterally located placenta.

In our study, the sensitivity was 75 , specificity was 81 , the positive predictive value was 48 and the negative predictive value was 96.

Conclusion: As yet, there is no practical, acceptable and reliable method for screening for preeclampsia that has been thoroughly tested and tried.

In view of the results of our study, ultrasonography in pregnant woman during 20 to 24 weeks of gestation can be a easy, noninvasive, useful and cost-effective tool as a predictor of preeclampsia.

Keywords: Preeclampsia, Predictor, Placenta.

How to cite this article: Bhalerao AV, Kulkarni S, Somalwar S. Lateral Placentation by U Itrasonography: A Simple Predictor of
Preeclampsia. J South Asian Feder Obst Gynae 2013;5(2): 68-71.

\section{Source of support: Nil \\ Conflict of interest: None declared}

\section{INTRODUCTION}

Preeclampsia is a disease of trophoblastic tissue. ${ }^{1}$ it is a complex clinical syndrome involving multiple organ systems and still remains the principle cause of maternal and perinatal morbidity and mortality.

The search for an ideal predictive test is still on, and preventive measures for preeclampsia remain challenging.

U terus receives most of the blood supply from uterine arteries- a branch of internal iliac artery. During pregnancy, the uterine site of placental implantation may be an important determinant of placental blood flow. Noninvasive Doppler studies of uterine arteries in second trimester reveal abnormal waveforms suggestive of defective uterine perfusion due to placental implantation, when one artery is the dominant supply of the intervillous flow. ${ }^{2,3}$

Placental location can be documented by various means, likeX -ray, isotopic placentography, etc. In the past two decades, ultrasound has proved to be the safest, easiest and most accurate method for assessing placental location. Placenta may be lateral in women with abnormal waveforms and this has been implicated in preeclampsia, IU GR, etc. ${ }^{4,5}$

\section{AIMS AND OBJECTIVES}

1. To examine the relation between placental location and development of preeclampsia.

2. To study the pregnancy outcome in terms of mode of delivery and birth weight of all babies.

\section{Research Question}

Does lateral placentation on ul trasonography at 20 to 24 weeks of gestation predict development of preeclampsia?

\section{MATERIALS AND METHODS}

After taking College Ethical Committee approval and after consent and counceling, a total of 486 pregnant women attending antenatal clinic of a tertiary care hospital were recruited in the study over a period of 2 years as per inclusion/ exclusion criteria.

\section{Inclusion Criteria}

Pregnant women with 20 to 24 weeks of gestation, with singleton pregnancy, attending antenatal clinic and ready for follow-up. 
Lateral Placentation by U Itrasonography: A Simple Predictor of Preeclampsia

\section{Exclusion Criteria}

1. Pregnant women less than 20 to 24 weeks of gestation.

2. Pregnant women with chronic hypertension, multiple pregnancy, uterine anomalies, previous cesarean section.

3. Women not willing for follow-up.

A detailed demographic history, gravidity, parity, history of abruption placenta, hypertension, preeclampsia, IUD, gestational diabetes were taken. General examination, including weight, blood pressure, vital signs, was done. Detailed obstetric examination was done.

UItrasonography was done for all women between 20 and 24 weeks of gestation and placenta was classified as central when it was between the RT and LT side of uterus irrespective of being anterior, posterior or fundal. When $75 \%$ or more of placenta was on one side of midl ine, it was classified as lateral.

All women with central and lateral placenta were followed up till development of preeclampsia as per A COG guidelines and later till delivery to see the outcome of pregnancy.

Pregnancy outcome thus was assessed to see

1. Incidence of preeclampsia with lateral location of placenta.

2. Incidence of lateral location of placenta in preeclampsia.

Data analysis was done using SPSS software, statistical significance less than 0.05 was significant. Sensitivity, specificity, positive predictive value, negative predictive value were found.

\section{OBSERVATIONS}

Of the 486 women, 23 women dropped out.

The maternal characteristics, like age, gravidity, parity, were compared in the centrally and laterally located placenta groups as shown in Table 1.

While recruiting, there was no bias on low-risk and highrisk groups but, at the end of the study we found 182 women with high-risk factors and 281 women with low-risk factors as shown in Table 2.

A total of 71 pregnant women developed preeclampsia, of whom 52/71(73.23\%) had laterally situated placenta. This relationship seems to be significant as shown in Table 3.

\begin{tabular}{lccc}
\multicolumn{4}{c}{ Table 1: The various characteristics } \\
\hline Characteristics & $\begin{array}{c}\text { Centrally located } \\
\text { placenta }\end{array}$ & $\begin{array}{c}\text { Laterally located } \\
\text { placenta }\end{array}$ & p-value \\
\hline Age & $24 \pm 6.1$ yrs & $23 \pm 6.3$ yrs & 0.12 \\
Gravidity & $2 \pm 1.2$ yrs & $1.9 \pm 1.3$ yrs & 0.44 \\
Parity & $0.6 \pm 0.8$ yrs & $0.6 \pm 0.7 \mathrm{yrs}$ & 1.0 \\
\hline
\end{tabular}

Table 2: The characteristics of study population

\begin{tabular}{lc}
\hline Characteristics & Number \\
\hline Primigravida & 162 \\
Previous history of preeclampsia, abruption & 06 \\
P revious history of IUGR, IUD & 09 \\
Diabetes & 03 \\
High-risk factors & 182 \\
Low-risk factors & 281 \\
\hline
\end{tabular}

Table 3: Placental position and development of preeclampsia

\begin{tabular}{lcc}
\hline Placental position & \multicolumn{2}{c}{ Development of preeclampsia } \\
\cline { 2 - 3 } & Yes $(n=71)$ & No $(n=392)$ \\
\hline Centrally located $(n=342)$ & $19(26.76 \%)$ & $323(82.39 \%)$ \\
Laterally located $(n=121)$ & $52(73.23 \%)$ & $69(17.60)$ \\
Chi-square-96.39 & p-value-0.001 \\
\hline
\end{tabular}

To see the effect of placental laterality in low risk and high risk groups the data was further analyzed and it was found that of the 281 women in low-risk group, 14 developed preeclampsia and in high-risk group 32 developed preeclampsia as shown in Tables 4 and 5.

As shown in Table 6, there was no relation of placental position and mode of delivary. The cesarean rate was $26.78 \%$. and normal delivaries being $73.21 \%$. Of the cesareans, 76 $(16.41 \%)$ were having centrally located placenta and 48 $(10.36 \%)$ had laterally located placenta.

Tables 7 and 8 show no association between the placentation and birth weight in all women and women who developed preeclampsia.

\section{DISCUSSION}

Preeclampsia is a multiorgan system clinical syndrome responsible for maternal and perinatal morbidity and mortality.

\begin{tabular}{|c|c|c|}
\hline \multirow{2}{*}{$\begin{array}{l}\text { Placental position } \\
(\mathrm{n}=281)\end{array}$} & \multicolumn{2}{|c|}{ Development of preeclampsia } \\
\hline & Yes $(n=23)$ & No $(n=258)$ \\
\hline $\begin{array}{l}\text { Centrally located } \\
\text { Laterally located }\end{array}$ & $\begin{array}{c}9(39.13 \%) \\
14(60.86 \%) \\
\text { Chi-square-48.02 }\end{array}$ & $\begin{array}{c}234(90.69 \%) \\
24(9.30 \%) \\
\text { p-value-0.001 }\end{array}$ \\
\hline
\end{tabular}

\begin{tabular}{|c|c|c|}
\hline \multirow{2}{*}{$\begin{array}{l}\text { Placental position } \\
(n=182)\end{array}$} & \multicolumn{2}{|c|}{ Development of preeclampsia } \\
\hline & Yes $(n=48)$ & No $(n=134)$ \\
\hline $\begin{array}{l}\text { Centrally located } \\
\text { Laterally located }\end{array}$ & $\begin{array}{c}16(33.33 \%) \\
32(66.66 \%) \\
\text { Chi-square-75.93 }\end{array}$ & $\begin{array}{c}126(94.02 \%) \\
8(5.97 \%) \\
\text { p-value-0.001 }\end{array}$ \\
\hline
\end{tabular}

Table 6: The mode of delivary in all women

\begin{tabular}{lcr}
\hline $\begin{array}{l}\text { Placental position } \\
(n=463)\end{array}$ & \multicolumn{2}{c}{ Mode of delivary } \\
\cline { 2 - 3 } & LSCS $(n=124)$ & ND $(n=339)$ \\
\hline Centrally located & $76(16.41 \%)$ & $266(57.45 \%)$ \\
Laterally located & $48(10.36 \%)$ & $73(15.76 \%)$ \\
\hline
\end{tabular}

Table 7: Relation between placental position and the birth weight

\begin{tabular}{lcc}
\hline $\begin{array}{l}\text { Placental position } \\
(n=463)\end{array}$ & \multicolumn{2}{c}{ Birth weight } \\
\cline { 2 - 3 } & Less than $2.5 \mathrm{~kg}$ & More than $2.5 \mathrm{~kg}$ \\
\hline Centrally located (342) & $188(54.97)$ & $154(45.02)$ \\
Laterally located (121) & $68(56.19)$ & $53(43.80)$ \\
\hline
\end{tabular}


Table 8: Relation between placental position and the birth weight in cases of preeclampsia

\begin{tabular}{lcc}
\hline $\begin{array}{l}\text { Placental position } \\
(n=71)\end{array}$ & \multicolumn{2}{c}{ Birth weight } \\
\cline { 2 - 3 } & Less than $2.5 \mathrm{~kg}$ & More than $2.5 \mathrm{~kg}$ \\
\hline Centrally located $(n=19)$ & $9(47.36)$ & $10(52.63)$ \\
Laterally located $(n=52)$ & $34(65.38)$ & $18(34.61)$ \\
\hline
\end{tabular}

In our systematic review of literature, location of placenta as a potential predictor of preeclampsia dates back to first study by K ofinas et al. ${ }^{4}$ They have reported 2.7 times high risk of developing preeclampsia in laterally located placenta so it is the likelihood of abnormal uterine artery waveforms in lateral placentas.

When the placenta is central, there is low resistance in both uterines. When the placenta is lateral, the uterine artery close to placenta has lower resistance than the opposite side. The placental blood flow needs are met with one of the uterine arteries and some contribution from other side uterine artery via the collateral circulation. The degree of collaterals may be deficient facilitating development of preeclampsia, IU G R, etc. and for normal cytotrophoblastic invasion normal placentation is essential.
Li ieberman et al ${ }^{6}$ found that placenta previa was associated with lower rate of preeclampsia due to wider and freer course of isthmic component of uterine artery.

In present study, out of 463 women, $71(15.33 \%)$ devel oped preeclampsia, of these $52(73.23 \%)$ had unilaterally located placenta and $19(26.76 \%)$ had centrally located placenta. This coincides with the study by Pai $M$ et $a^{14} 52 / 426$ (73\%) and Kofinas et al ${ }^{4,5} 20 / 34$ (74\%).

Present study shows that women with lateral placenta have a 2.7 times more risk of developing preeclampsia which is same by Pai $\mathrm{M}$ et al, ${ }^{14}$ and $\mathrm{K}$ ofinas et al ${ }^{4}$ (2.8 times).

In our study, the sensitivity was 75 , specificity was 81 , the positive predictive value was 48 and the negative predictive value was 96 . These can be compared with other tests mentioned by Chan et al. ${ }^{15}$

There was no association between placentation and mode of delivary. Birth weight was al so not associated with placental location, this coincides with all the studies shown in the table below. As yet, there is no practical, acceptable and reliable method (Table 9) for screening for preeclampsia that has been thoroughly tested and tried.

In view of the results of our study, ultrasonography in pregnant woman during 20 to 24 weeks of gestation can be a

\begin{tabular}{|c|c|c|c|c|}
\hline Study & Sample size & $\begin{array}{l}\text { Ultrasound } \\
\text { timing (weeks) }\end{array}$ & IUGR/SGA & Preeclampsia \\
\hline Kofinas et al, $1989^{4}$ & $\begin{array}{l}311 \text { total } \\
153 \text { normal }\end{array}$ & $24-40$ & $\begin{array}{l}\text { IUGR } 2.7 \times \text { more likely in } \\
\text { cases with lateral placenta }\end{array}$ & $\begin{array}{l}\text { PIH } 2.8 \times \text { more likely in } \\
\text { cases with lateral placenta }\end{array}$ \\
\hline Lieberman et al, $1991^{6}$ & $\begin{array}{l}106866 \\
491 \text { placenta previa } \\
106375 \text { not }\end{array}$ & Not defined & 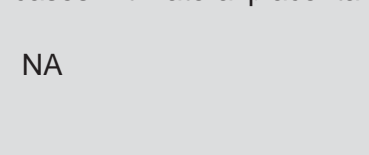 & $\begin{array}{l}\text { Decrease incidence of } \\
\text { preeclampsia in women } \\
\text { with placenta previa }\end{array}$ \\
\hline Wolf et al, $1991^{7}$ & $\begin{array}{l}342 \text { total } \\
171 \text { placenta previa } \\
171 \text { not }\end{array}$ & Not defined & No significant association & $\begin{array}{l}\text { Excluded pregnancies with } \\
\text { preeclampsia }\end{array}$ \\
\hline Liberati et al, $1997^{8}$ & $\begin{array}{l}732 \text { total } \\
481 \text { lateral } \\
251 \text { central }\end{array}$ & $22-24$ & $\begin{array}{l}\text { No significant association } \\
\text { between IUGR and lateral } \\
\text { placenta }\end{array}$ & $\begin{array}{l}\text { No significant association } \\
\text { between PIH and lateral } \\
\text { placenta }\end{array}$ \\
\hline Ito et al, $1998^{9}$ & $\begin{array}{l}106 \text { total } \\
86 \text { normal } \\
20 \text { IUGR }\end{array}$ & $33-38$ & $\begin{array}{l}\text { Higher UARI on placental } \\
\text { side in cases with lateral } \\
\text { placenta than in central } \\
\text { placenta in IUGR infants }\end{array}$ & No significant association \\
\hline Kalaniti et al, $2007^{10}$ & $\begin{array}{l}272 \text { total } \\
67 \text { IUGR } \\
205 \text { normal }\end{array}$ & $16-20$ & $\begin{array}{l}\text { IUGR babies } 3.8 \times \text { more } \\
\text { likely to have lateral } \\
\text { placenta }\end{array}$ & NA \\
\hline Present study & $\begin{array}{l}463 \text { total, } 342 \text { central } \\
121 \text { lateral }\end{array}$ & $20-24$ & No significant association & $\begin{array}{l}2.7 \text { times increased risk of } \\
\text { preeclampsia in lateral } \\
\text { placenta }\end{array}$ \\
\hline Magann et al, $2007^{11}$ & $\begin{array}{l}3336 \text { total, } 2914 \text { fundal, } \\
328 \text { lateral } \\
93 \text { low }\end{array}$ & $14-40$ & No significant association & No significant association \\
\hline Belogolovkin et al, ${ }^{12} 2007$ & 292 twins & 20 & No significant association & No significant association \\
\hline Devrajan K et al, $2012^{13}$ & $\begin{array}{l}799 \text { total,133 lateral } \\
663 \text { fundal }\end{array}$ & $6-24$ & No significant association & No significant association \\
\hline Pai M et al, $2005^{14}$ & $\begin{array}{l}426 \text { total, } 324 \text { central } \\
102 \text { lateral }\end{array}$ & $20-24$ & - & $\begin{array}{l}2.7 \text { times increased risk of } \\
\text { preeclampsia in lateral } \\
\text { placenta }\end{array}$ \\
\hline
\end{tabular}


Lateral Placentation by Ultrasonography: A Simple Predictor of Preeclampsia

\begin{tabular}{lcccc}
\hline \multicolumn{2}{c}{ Table 9: Screening tests for preeclampsia } \\
\hline Screening test & Sensitivity (\%) & Specificity (\%) & $\begin{array}{c}\text { Positive predictive } \\
\text { value (\%) }\end{array}$ & $\begin{array}{c}\text { Negative predictive } \\
\text { value (\%) }\end{array}$ \\
\hline Mid-trimester BP & 44 & 87 & 9 & 98 \\
Urinary alb/creat. ratio & 64 & 84 & 43 & 94 \\
Platelet angiotensin 2 binding & 81 & 96 & 81 & 96 \\
Abnormal RI on Doppler & 47 & 81 & 44 & 83 \\
Placental laterality & 73 & 86 & 51 & 94 \\
\hline
\end{tabular}

easy, noninvasive, useful and cost-effective tool as a predictor of preeclampsia.

\section{REFERENCES}

1. Walker JJ. Current thoughts on pathophysiology of preeclampsia leclampsia. In: John Stud editors. Progress in obstetrics and gynaecology, Edinburg Churchill, Livingstone 1998:177-188.

2. Fleischer $A$, Schulman $H, F$ armakidis $G$, et al. U terine artery Doppler velocimetry in pregnant women with hypertension. AM . J Obstet Gynaecol 1986:154:806-813.

3. Schulman H. W inter D, Farmakides G, et al. Pregnancy surveillance with Doppler velocimetry of uterine and umbilical arteries. AM J Obstet Gynaecol 1989:160:192-196.

4. K ofinas A D, Penry M, Swain M , Hatjis C G. Effect of placental laterality on uterine artery resistance and development of preeclampsia and intrauterine growth retardation. A m J Obstet Gynecol 1989:161:1536-1539.

5. K ofinas AD, Penry M, G reiss FC, M eis PJ, et al. The effect of placental location on uterine atery flow velocity waveforms. A M J Obstet Gynaecol 1988;159:1504-1508.

6. L eiberman J r, Fraser J, Kasis A, M azor M. Reduce frequency of hypertensive disorder and placenta previa. O bstat Gynaecol 1991:77:83-610.

7. Wolf EJ, Mallozzi A, Rodis JF, Egan JF, Vintzileos AM, Campbel W A. Placenta previa is not an independent risk factor for a small for gestational age infant. Obstat Gynaecol 1991:77:707-709.

8. Liberati M, Rotmensch, Zanolli P, Perinno S, Celentano C, Tiboni GM , et al. U terine artery Doppler velocimetry in pregnant women with lateral placenta. J Perinat M ed 1997:25:133-185.

9. Ito $Y$, Shono M, U chiyama A, Suigimori H. Resistance index of uterine artery and placental location in intrauterine growth retardation. A ceta O bstet Gynecol Scand 1998:77:385-909.

10. Kalanithi LE, Illuzzi J L, N ossov V B, Frisback Y, A bdel-R azeq S, Copel J A, et al. Intrauterine growth restriction and placental location. J Ultrasound M ed 2007:26:1481-1489.
11. M agann EF, Doherty DA, T urner K, L anneau GS J r, M orrison JC, N ewnham JP. Second trimester placenta; Location as a predictor of an adverse pregnancy outcome. J Pernatol 2007:27:9-14.

12. Belogolovkin V, Engel SM, Ferrara L, Eddleman KA, Stone $J \mathrm{~L}$. D oes sonographic determination of placental location predict fetal birth weight in diamniotic-dichorionic twins? J U Itrasound Med 2007:26:187-191.

13. Devrajan K, K ives S. Placental location and newborn weight. J Obstet Gynaecol Can 2012;34(4);325-329.

14. Pai M V, Pillai J. Placental laterality by ultrasound-a simple yet reliable predictive test for preeclampsia. J O bstet Gynaecol India 2005 Sep-Oct; 55(5).

15. Chan FY, Pun TC, et al. Pregnancy screening by uterine artery Doppler velocimetry - which criterion performs best? Obstet Gynaecol 1995;85;596-602.

\section{ABOUT THE AUTHORS}

\section{Anuja V Bhalerao}

A ssociate Professor, Department of O bstetrics and Gynecology, NK P Salve Institute of M edical Sciences, Nagpur, M aharashtra, India

Correspondence Address: C/O Dr V M B halerao, 494, Old Ramdaspeth, Nagpur-440010, M aharashtra, India, Phone: 07122427026/09823680572, e-mail: vivek_bhalerao@yahoo.com

\section{Sayali Kulkarni}

Resident, Department of Obstetrics and Gynecology, NKP Salve Institute of M edical Sciences, Nagpur, M aharashtra, India

\section{Savita Somalwar}

Lecturer, Department of Obstetrics and Gynecology, NKP Salve Institute of M edical Sciences, Nagpur, M aharashtra, India 